\title{
POLITICA, PRECONCEITO, IDEOLOGIA E ANTIPETISMO NAS PÁGINAS DE DIREITA DO FACEBOOK NO ANO ELEITORAL DE 2014
}

\author{
Eliana Batista Ramos \\ Mestra em História Social pela Pontifícia Universidade Católica de São Paulo. \\ anaileramos@hotmail.com
}

resumo: As redes sociais ocupam um lugar de destaque na sociedade contemporânea. Elas podem se configurar como oportunidades de relacionamentos interpessoais tanto quanto como canais de disseminação de ideias, ideologias sociopolíticas e preconceitos. Uma das redes sociais mais populares do mundo, o Facebook, será evidenciada nesse artigo como, para além de um espaço de sociabilidades, um campo privilegiado de disputas políticas e ideológicas que ajudam a manter o poder da classe hegemônica. Neste texto, a propagação de concepções embasadas no preconceito e as disputas incitadas pelos posicionamentos contrários ao Partido dos Trabalhadores (PT), serão enfocadas, assim como a conflituosa dualidade Esquerda/Direita, observada no ano eleitoral de 2014 nas páginas do Facebook.

Palavras-Chave: Ideologia, Antipetismo, Facebook. abstract: Social networks occupy a prominent place in contemporary society. They can be configured as interpersonal relationships opportunities as dissemination channels of ideas, sociopolitical ideologies and prejudices. One of the most popular social networks in the world, Facebook, will be shown in this article as, in addition to a sociability space, a privileged field of political and ideological disputes that help keep the power of the hegemonic class. In this text, the spread of ideas informed by prejudice and disputes incited by positions contrary to the Workers Party (PT), will be focused, as well as the conflicting duality Left / Right, observed in the election year 2014 on Facebook pages.

Keywords: Ideology, Antipetismo, Facebook. 
comunicação entre as pessoas ea velocidade com que as informações chegam aos seus usuários se configuram como uma revolução nas trocas de experiências, conhecimentos e de relacionamentos na sociedade contemporânea. N este contexto, os Sites de Redes Sociais (SRS) ganharam um espaço considerável. Eles funcionam como redes de comunicação intrincadas earticuladas que oferecem ferramentas de compartilhamento de pensamentos, ideias, sentimentos, posturas ideológicas e políticas, dentre outras coisas.

O Facebook, como uma dessas redes e a mais popular delas, agrega em suas páginas milhões de pessoas em todo o mundo. 0 sitesurgiu:

[.] em 4 de fevereiro de 2004, e de propriedade privada da Facebook Inc, fundado por Mark Zuckerberg. A tualmente é o SRS mais acessado no mundo - apenas no Brasil, estimase que 67 milhões de pessoas utilizam o serviço.A través do site, usuários criam perfis com informações e interesses pessoais e passam a se relacionar com outros usuários. O Facebook é gratuito e obtêm receita proveniente de publicidade, incluindo banners, destaques patrocinados no feed de notícias e de grupos patrocinados. ${ }^{1}$

A lém disso, tal rede social permite que seus usuários estabeleçam contatos com amigos do mundo real e que também travem conhecimento com outros usuários que, geralmente, resumem-se ao mundo virtual. As trocas de ideias e experiências no bojo de redes sociais como o Facebook é profícua, pois suas ferramentas permitem que as discussões travadas em suas páginas se tornem públicas.

${ }_{1}^{1}$ RIBEIRO, José Carlos; BARBERINO, Lisieanne Araújo. Tribunal Do Facebook: um estudo sobre sistemas de acusação nos sites de redes sociais. 2013. Disponível em: <http://gitsufba.net/anais/wpcontent/uploads/2013/09/13n1_tribunal_49896.pdf>. Acesso em: 15/06/2015.

KaHos, E. B. FoLÍtica, Freconceito, ideoloğia e antipetismo nas pásinas de direita do facebook no ano eleitaral de 2014.

albuquerque: revista de historia. val. 9, n. 17, jan.-jul. de 2017, p. 206-236. 
Embora as postagens possam não ser tão evidenciadas conforme as configurações da conta escolhidas pelos usuários, o perfil das pessoas que se agregam ao Facebook é público, qualquer pessoa pode acessar e verificar.

A maioria dos internautas que adere a essa rede social justifica sua entrada e permanência nela pelas possibilidades de conhecer novas pessoas ou de reestabelecer contato com outras que já haviam ficado no passado. Esses sujeitos consideram o Facebook como uma mídia facilitadora de contatos e de troca de informações. A pesar desses fatores positivos, o Facebook também vem se configurando como o veículo que denota uma teia de relações sociais conflituosas no tocante às discussões polêmicas as quais abre espaço.

Pode-se considerar que atualmente a Internet e as redes sociais têm tanto poder de interferir na opinião pública tanto quanto a imprensa. "Seria tolice ignorar que eles não são apenas o meio de expressão de espíritos independentes, mas também, e com muito mais frequência, de grupos de pressão diversos, políticos ou financeiros" 2.0 autor ainda chama atenção ao apontar que ter apenas a imprensa como termômetro da opinião pública pode apresentar fal has em épocas de censura, por exemplo. Em contrapartida, pode-se afirmar que as concepções que emanam das redes sociais são livres e só existem em Estados democráticos, o que torna as análises muito mais contundentes.

Percebe-se que o uso indiscriminado das redes sociais no Brasil tem se apropriado do poder de levantar discussões e debates sobre temas importantes, social e politicamente, baseados em fontes seguras, tanto quanto vem tendo 0 mesmo poder de proliferar inverdades e de incitar debates rasos, repletos de juízo de valor, sem qualquer embasamento. Pode-se perceber também que muitas das informações veiculadas via Facebook logo se espalham e "viralizam" como verdadeiras sem que as fontes sejam checadas ou o fato pesquisado.

A pós os protestos ocorridos em 2013 , conclamados também via redes sociais, pôde-se notar que, além do evidente poder de comunicação entre as pessoas, sites como o Facebook também podem se configurar como veículos de disseminação de ideias e de ideologias que nem sempre são atreladas ao bom senso. Posicionamentos ideológicos e políticos dos usuários emanam das telas dos computadores e geram discussões acaloradas que podem ser acompanhadas publicamente e gerar desconforto.

Tanto no grupo de amigos que cada um delimita nesta rede social quanto fora dele, é possível encontrar conteúdos preconceituosos ou de origem duvidosa, com análises superficiais e tendenciosas de fatos políticos e históricos, o que parece

${ }^{2}$ BECKER, Jean-Jacques. A Opinião Pública. In: RÉMOND, René. Por uma História Política. 2. ed. Rio de Janeiro: Editora FGV, 2003, p. 196.

Kayos, E. B. Folítica, Freconceito, idealogita e antipetismo nas pásinas de direita do facebook no ano eleitaral de 2014.

albuquerque: revista de historia. val. 9, n. 17, jan.-jul. de $2017, p \cdot 206-236$. 
não preocupar a maioria dos usuários, embora tenham influência sobre sua visão de mundo, exposta no que curtem ou compartilham.

Nas inúmeras páginas do Facebook, as temáticas tratadas são variadas e algumas logo se transformam em extensos debates, principalmente quando envolvem questões político-partidárias, o que ficou bem mais enfático em 2014, ano eleitoral.

Neste sentido, a intolerância ganhou um espaço considerável em determinados grupos e páginas do Facebook e, com isso, a proliferação de intrigas de caráter ideológico também.

\section{subjetividades exaltadas na rede}

A maior parte do conteúdo encontrado, postado e compartilhado no Facebook vem se transformando em discurso pronto de internautas nas redes e nas ruas. É comum que discursos preconceituosos sejam observados tanto nessa rede social quanto nas conversas travadas pessoalmente construídas nas sociabilidades cotidianas dos sujeitos. Temáticas como cotas raciais, maioridade penal, feminismo, direitos humanos e, principalmente, a economia e o contexto sócio-político brasileiro vieram à tona através da Internet, transformando-se em um palco de discussões acaloradas, causadora de uma dualidade de posicionamentos que vem gerando sérias intrigas.

Segundo a análise de Gilles Lipovetsky³ , a contemporaneidade é marcada pelo fenômeno da pós-moralidade permeada por valores subjetivos e não mais comuns, como já o foram quando marcados por laços nascidos da comunidade. $A$ pós-moralidade não culmina no fim da moral, mas a transforma, segundo os limites constituídos individualmente, dentro das concepções de mundo validadas por cada um.

Diante disso, pode-se considerar que:

Com o desmoronamento dos grandes discursos normativos acerca da moral, assiste-se a fenômenos inéditos que participam de um individualismo irresponsável: cinismo generalizado, recusa do esforço e do sacrifício individuais, comportamentos compulsivos, tráfico de drogas e toxicomania, violência gratuita, particularmente com relação às mulheres nas periferias urbanas. 0 reino do hedonismo coincide apenas em parte com a era da tomada de responsabilidade 4

\footnotetext{
${ }^{3}$ LIPOVETSKY, Gilles. Os Tempos Hipermodernos (com Sébastien Charles). Trad. Mário Vilela. São Paulo: Barcarolla, 2004, p. 39.

${ }^{4}$ Idem.

KaHos, E. B. FOLÍtica, Freconceito, ideolosia e antipetismo nas pásinas de direita do facebaok no ano eleitaral de 2014.

albuquerque: revista de historia. val. 9, n. 17, jan.-jul. de 2017, p. 206-236.
} 
Cada sujeito, a seu modo, delimita o que considera ou não ofensivo. N o caso das redes sociais, os limites entre o que é ou não ético são tênues. Os sujeitos se revestem das personalidades engendradas por cada um nestes espaços e se sentem mais livres. Forjam companhias, ideias, deturpam fatos reais e escrevem o que querem a respeito de tudo e de todos.

É certo que o individualismo é latente na contemporaneidade, o que muitas vezes se traduz em solidão. Pode ser essa uma das razões para o aumento massivo do público conectado virtualmente através de redes como o Facebook. Segundo a ótica de Bauman ${ }^{5}$, tal ideia é plausível quando afirma que:

Hoje em dia, nada nos faz falar de modo mais solene ou prazeroso do que as "redes" de "conexão" ou "relacionamentos", só porque a "coisa concreta" - as redes firmemente entretecidas, as conexões firmes e seguras, os relacionamentos plenamente maduros praticamente caiu por terra.6

A facilidade de conectar pessoas e comunidades unidas por determinados gostos ou formas de pensamento faz das redes de relacionamento um "oásis social" no estreitamento do contato entre os sujeitos, mas nem sempre dos laços af etivos, o que pode ser explicado pelo fato de:

[...] expostos aos "contatos facilitados" pela tecnologia eletrônica, perdemos a habilidade de nos engajar em interações espontâneas com pessoas reais. $\mathrm{Na}$ verdade, ficamos com vergonha dos contatos frente a frente. Tendemos a pegar os celulares e apertar furiosamente as suas teclas e escrever mensagens a fim de escaparmos de ser transformados em reféns do destino - no intuito de escaparmos de interações complexas, confusas, imprevisíveis, difíceis de interromper e de abandonar com as "pessoas reais" que estão fisicamente à nossa volta. Ouanto mais amplas (ainda que mais superficiais) são as nossas comunidades fantasmas, mais atemorizante parece a tarefa de construir e manter as verdadeiras?

${ }^{5}$ BAUMAN, Zigmunt. Identidade (Entrevista a Beneetto Vecchi). Rio de Janeiro: Jorge Zahar Ed., 2005, p. 100.

Idem.

${ }^{7}$ Ibidem, p. 101.

KaHos, E. B. FoLÍtica, Freconceito, ideoloğia e antipetismo nas pásinas de direita do facebook no ano eleitaral de 2014.

albuquerque: revista de historia. val. 9, n. 17, jan.-jul. de 2017, p. 206-236. 
A tela do computador tem o poder de aproximar as pessoas e de afastá-las ao mesmo tempo. Os contatos virtuais são menos abrasivos do que os reais no sentido afetivo da ideia. No entanto, ou até mesmo em decorrência disso, as discussões virtuais acerca do mundo físico tomam proporções muito maiores do que as que poderiam ter no contato pessoal. A trás dessas telas, direto das salas de suas casas ou de outros lugares cotidianos, cidadãos postam suas visões de mundo e assumem militância por causas diversas, de forma superficial, muitas vezes permeada pelos discursos ideológicos dominantes, o que vem gerando infindáveis discussões que tem alcançado um nível de estresse e de violência verbal extremo.

No contato real, isso poderia ser evitado, ou diminuído, já que no "face a face" é possível observar o olhar, os gestos, a expressão facial, as falas do corpo que interferem nas posições tomadas pelos interlocutores.

Por outro lado, segundo Lipovetsky:

[...] ao possibilitar o acesso a uma informação cada vez mais diversificada e mais caracterizada por pontos de vista diferentes, propondo uma gama extremamente variada de escolhas, a mídia permitiu que se desse aos indivíduos maior autonomia de pensamento e de ação, com a oportunidade de constituir opinião própria sobre um número sempre maior de fenômenos.

N o entanto, as redes sociais também emanam uma liberdade que se sobressai à ética e ao bom senso, o que ajuda a formar opiniões empobrecidas de análise, baseadas no senso comum. Porém, segundo Canclini, ${ }^{9}$ o distanciamento entre os sujeitos na sociedade atual não foi perdido nas relações capitalistas, pois a despeito de qualquer vínculo solidário, constituem-se "[.] comunidades hermenêuticas de consumidores ${ }^{" 10}$, o que para o autor não é de todo ruim, pois acredita que essa via também pode facilitar a formação de "[...] associações de consumidores e lutas sociais, ainda que em grupos marginais, melhor informadas sobre as condições nacionais e internacionais [..." $]^{11}$.A pesar disso, pode-se perceber também "[... que as comunidades construídas em torno de afinidades esportivas ou gostos musicais, por exemplo, podem reavivar os estereótipos fundamentalistas e racistas do nacionalismo [.] ou violências geracionais $[. .]^{12}$, mesmo que a ligação entre os membros do grupo não tenha tido esta gênese.

\footnotetext{
${ }^{8}$ LIPOVETSKY, Gilles. op. Cit., p. 42.

${ }^{9}$ CANCLINI, Néstor García. Consumidores e Cidadãos: conflitos multiculturais da Globalização. 7. ed. Trad. Maurício Santana Dias. Rio de Janeiro: Editora UFRJ, 2008, p. 224.

${ }^{10}$ Idem.

${ }^{11}$ Idem.

${ }^{12}$ Idem.

RAMOS, E. B. FOLÍTCA, Freconceito, ideolosia e antipetismo nas pásinas de direita do facebook no ano eleitaral de 2014.

albuquerque: revista de historia. val. 9, n. 17, jan.-jul. de $2017, p \cdot 206-236$.
} 
É preciso enfatizar e considerar que, no bojo deste contexto:

[.] é certo que as condições em que a sociedade civil pode falar consigo mesma mudaram estruturalmente. Enquanto as ações de massa não desenvolvam intervenções adequadas à extensão e eficácia da mídia, prevalecerão as dissidências atomizadas, os comportamentos grupais erráticos, conectados mais pelo imaginário do consumo do que por desejos comunitários. ${ }^{13}$

Essas asserções apontam para uma apropriação constante dos modelos midiáticos da sociedade atual pelo mercado capitalista, a fim de ampliar a sua rede de consumidores. E estes, por sua vez, nas comunidades virtuais, podem se "desengajar" cada vez mais de sua condição social.

Corroborando essa linha de pensamento, Bauman ${ }^{14}$ afirma que:

Hojeem dia, [.] somos consumidores numa sociedade de consumo. A sociedade de consumo éa sociedade de mercado.Todos estamos dentroe nomercado, ao mesmo tempo clientes emercadorias. N ão admira que o uso/consumo das relações humanas, e assim, por procuração, também de nossas identidades (nós nos identificamos em referência a pessoas com as quais nos relacionamos), se emparelhe, e rapidamente, com o padrão de uso/consumo de carros, imitando o ciclo de consumo que se inicia na aquisição e termina no depósito de supérfluos. (Grifos do autor)

N este sentido, ao formar ou fazer parte de uma rede comunicacional virtual que agregue pessoas das mais diversas classes sociais e culturas, pode dar a sensação de pertencimento necessária a quem geralmente é excluído no mundo real.

A cultura de massas podefacilitar esse pertencimento imaginário, já quenela "[..] o massivo [..] não é um mecanismo isolável, ou um aspecto, mas uma nova forma de sociabilidade"15. A o refletir sobre o caráter hegemônico da TV , o autor conclui que "o modelo hegemônico de televisão 'odeia as diferenças ${ }^{\text {"16 }}$ e vai além, ao citar o caso daTV peruana que deu vazão ao popular massivo em sua programação através de programas cômicos.

O autor acredita que:

${ }^{13}$ CANCLINI, Nestor Garcia. op. cit., p. 225.

${ }^{14}$ BAUMAN, Zigmunt. op. cit., p. 98.

${ }^{15}$ MARTÍN-BARBERO, Jesús. Dos Meios Às Mediações: Comunicação, Cultura e Hegemonia. 4. ed. Rio de Janeiro: Editora UFRJ, 2006, p. 311.

16Idem.

Kanos, E. B. FoLÍtroa, Freconceito, idealogia e antipetismo nas pásinas de direita do facebook no ano eleitaral de 2014.

albuquerque: revista de historia. val. 9, n. 17, jan.-jul. de 2017, p. 206-236. 
É só no espaço da comicidade que a televisão se atreve a deixar ver - povo, esse "feio povo" que a burguesia racial quis a todo custo ocultar. Só aí é que a televisão se trai, ao mostrar sem pudor as faces do povo. Mais uma vez, o realismo grotesco do cômico se faz espaço de expressão dos de baixo, que nele se dão uma face e apresentam suas armas, sua capacidade de paródia e caricatura.17

Essa reflexão se refere à TV, mas, ao se pensar nas redes sociais, principalmente no Facebook, através da qual se pode ser quem é ou se reinventar conforme a última moda ou as necessidades de pertencimento adjacentes a cada um, tal pensamento é válido. Nessa rede de relacionamentos, as comunidades ou grupos de interesses comuns são abertos, não excluem ninguém. Deles podem fazer parte sujeitos de qualquer etnia ou classe social. N o entanto, as identificações criadas são tênues e denotam a fragilidade do pertencimento imaginado quando se torna evidente que tais comunidades também agregam preconceitos traduzidos em postagens repletas de juízo de valor pertencentes à parcela da classe econômica hegemônica.

\section{ideologias e preconceito na rede}

O viés ideológico se torna necessário a essa análise quando se pode perceber que os discursos mais exaltados, sobre assuntos polêmicos, encontrados no Facebook são permeados por ele. Segundo Marilena Chauí ${ }^{18}$, pode-se entender ideologia como sendo um:

[.] conjunto lógico, sistemático e coerente de representações (ideias e valores) e de normas ou regras (de conduta) que indicam e prescrevem aos membros da sociedade o que devem pensar e como devem pensar, o que devem valorizar e como devem valorizar, o que devem sentir e como devem sentir, o que devem fazer e como devem fazer.

Essa receita engendrada nos meandros das ideologias não vem pronta, mas nasce segundo as especificidades de cada contexto e de como a classe social hegemônica pode garantir a perpetuação de sua condição social e política.

Pode-se considerar que:

${ }^{17}$ Ibidem, p. 320.

${ }^{18} \mathrm{CHAUI}$, Marilena. $\mathrm{O}$ que é ideologia. 2. ed. São Paulo: Brasiliense, 2001, p. 108-9.

Kamos, E. B. FoLÍtica, Freconceito, ideoloğia e antipetismo nas pásinas de direita do facebook no ano eleitoral de 2014.

albuquerque: revista de historia. val. 9, n. 17, jan.-jul. de 2017, p. 206-236. 
[.] toda a ideologia representa, na sua deformação necessariamente imaginária, não as relações de produção existentes (e as outras relações que delas derivam), mas antes de mais a relação (imaginária) dos indivíduos com as relações de produção e com as relações que delas derivam. Na ideologia, o que é representado não é o sistema das relações reais que governam a existência dos indivíduos, mas a relação imaginária destes indivíduos com as relações reais que vivem. ${ }^{9}$

Essas relações imaginadas são construídas com base na ideologia dominante que apregoa uma naturalização das condições sociais vigentes na sociedade capitalista e que jamais releva ou mesmo considera a existência da luta de classes apontada pela teoria marxista. A Ithusser, em suas análises do legado literário de Karl Marx, aponta que "[.] toda ideologia tem por função (que a define) 'constituir' os indivíduos concretos em sujeitos ${ }^{20}$, mas não no sentido amplo de sujeito como ser participativo e de direitos, mas no de sujeição, de sujeitar-se passivamente às condições sociais nas quais vive, vendo-as com naturalidade. Deste modo, "[..] o indivíduo é interpelado como sujeito (livre) para que se submeta, livremente, às ordens do Sujeito, portanto para que aceite (livremente) a sua sujeição [-] e os atos da sua sujeição"21.

Essa forma característica de ver o mundo é o que se sustenta com base na ideologia da classe dominante. A ideia que se faz presente aí é a de que não há conflitos porque as condições sociais e econômicas vigentes não são conflitantes.

Sob a ótica marxista de Marilena Chauí, pode-se definir ideologia como sendo também um "[.] processo pelo qual as ideias da classe dominante tornam-se ideias de todas as classes sociais, tornam-se ideias dominantes" ${ }^{22}$. Como resultado, o sujeito de qualquer classe social tem as ideologias da elite como verdades absolutas, enquanto elas são esboçadas e engendradas por tal classe social para se auto afirmar e manter seu poder hegemônico. Deste modo, a classe dominante consegue negar, veementemente, a importância do reconhecimentoda estratificação social e da luta de classes inerentes às sociedades capitalistas. Tais ideologias servem para impedir que a dominação e a exploração que permeiam a sociedade de classes sejam vistas no âmbito da crítica, mas sim como "realidades" naturais a qualquer sociedade moderna, focada num suposto progresso.

\footnotetext{
${ }^{19}$ ALTHUSSER, Louis.Ideologia e Aparelhos ideológicos de estado. Lisboa: Presença, 1970, p. 82.

20Ibidem, p. 94.

${ }^{21}$ Ibidem, p. 113.

${ }^{22} \mathrm{CHAUÍ}$, Marilena. Op. cit., p. 84.
}

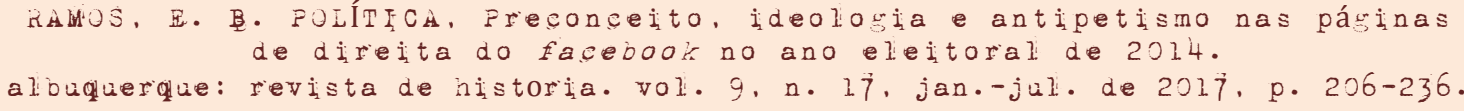


Sob a ótica de Althusser, para além da teoria marxista que apregoa que "[] o A parelho de Estado (A E) compreende: o Governo, a A dministração, o Exército, a Polícia. os tríbunaiss, as Prisões, etc. [..."23, em suas conclusões ele definiu os chamados A E como: "[.] A parelho Repressivo de Estado. Repressivo indica que o A parelho de Estado em questão 'funciona pela violência' - pelo menos no limite (porque a repressão, por exemplo, administrativa, pode revestir formas não físicas.)."24

Seguindo essa mesma lógica, A lthusser ${ }^{25}$ ainda pôde perceber e definir que os rumos ideológicos que procuram manter inalteradas as relações de produção existentes, e ainda as proliferar indefinidamente, só se sustentam pelo que o pensador chamou de "aparelhos ideológicos de Estado"26.

Tais aparelhos podem ser definidos como instâncias sociais que agregam grande contingente de pessoas, como as igrejas ou as escolas, e que proliferam ideologias.

Esta ideologia fala dos actos: nós falaremos de actos inseridos em práticas. E faremos notar que estas práticas são reguladas por rituais em que elas se inscrevem no seio da existência material de um aparelho ideológico, mesmo que se tratedeuma pequeníssima parte deste aparelho: uma missa pouco frequentada numa capela, um enterro, um pequeno desafio de futebol numa sociedade desportiva, um dia de aulas numa escola, uma reunião ou um meeting de um partido político, etc. ${ }^{27}$

Segundo A lthusser, a escola seria um dos aparehos ideológicos do Estado mais fortes, pois, sob a sua ótica:

[.] nenhum A parelho Ideológico de Estado dispõe durante tanto tempo de audiência obrigatória (e ainda por cima gratuita-), 5 a 6 dias em 7 que tem a semana, à razão de 8 horas por dia, da totalidade das crianças da formação social capitalista. ${ }^{28}$

\footnotetext{
${ }^{23}$ ALTHUSSER, Louis. Op. cit., p. 42-3.

${ }^{24}$ Idem.

${ }^{25}$ ALTHUSSER, Louis. Aparelhos ideológicos de estado: Nota sobre os aparelhos ideológicos de estado. 3. ed. Rio de Janeiro: Graal, 1985, p. 19.

${ }^{26}$ Idem.

${ }^{27}$ ALTHUSSER, Louis. Op. cit., 1970, p. 87.

28Ibidem, p. 66.

Ramos, E. B. Folítica, Freconceito, ideolognia e antipetismo nas pásinas de direita do facebook no ano eleitoral de 2014.

albuquerque: revista de historia. val. 9, n. 17, jan.-jul. de $2017, \mathrm{p} \cdot 206-236$.
} 
Isso podeser constatado em qual quer sociedade, relevando as subjetividades de cada uma, os tempos prédefinidos para que a criança se mantenha em ambiente escolar, dentre outras características. A despeito disso, caberessaltar que, atualmente, as redes sociais já podem ter tomado para si este papel. Segundo Leonardo Tristão, diretor-geral do Facebook no Brasil, o País estava atrás apenas dos EU A em números de acessos diários ao site, que em 2013 já contava com 47 milhões de brasileiros que acessavam e voltavam a acessar seus perfis diariamente ${ }^{29}$. Para uma população de pouco mais de 200 milhões de habitantes, segundo o último censo do Instituto Brasileiro de Geografia e Estatística (IBGE), em 2016 o acesso ao Facebook já ultrapassou os 99 milhões de usuários ${ }^{30}$, quase metade da população brasileira tem acesso e perfil no Facebook, o que ajuda a corroborar a ideia de sua capacidade de alcance.

Por outro lado, o Censo Escolar de 2014 registrou 48,9 milhões de alunos matriculados na Educação Básica entre as escolas públicas e privadas, segundo o site do $\mathrm{Gl}^{31}$, incluindo as matrículas de crianças em fase de alfabetização que ainda não têm perfil. Evidente que o comparativo entre acesso em uma rede social e matrículas na escola não tem o mesmo peso, no entanto, os dados contribuem com a visão de que a escola não ocupa mais a posição principal de aparelho ideológico de Estado, mas a divide com outros meios, inclusive com as mídias sociais.

A pesar de A lthusser considerar que quando adentra os espaços escolares a "[.].] criança está mais 'vulnerável', entalada entre o aparelho de Estado familiar e o aparelho de Estado Escola [..."32, podese considerar que adolescentes e adultos também possam ser "vulneráveis" às ideologias que emanam da tela de seus aparelhos eletrônicos quando se inserem em espaços virtuais.

A elite econômica que semprese assegura do poder político também, de uma forma ou de outra, preocupa-se em formar sujeitos que neguem ou desconheçam sua própria história e condição social em nome de outra fictícia, inventada, mas aparentemente real, moldada pela ideologia. A luta de classes, inerente ao capitalismo, fica esvaziada pela ideia que alguns sujeitos alimentam de que todos têm acesso às mesmas oportunidades na sociedade.

Com base nessa afirmação, Marilena Chauí enfoca a ideia de que:

\footnotetext{
${ }^{29} \mathrm{GOMES}$, Helton Simões. G1. Brasil é o $2^{\circ}$ país com mais usuários que entram diariamente no Facebook. 12/09/2013. Disponível em: <http://g1.globo.com/tecnologia/noticia/2013/09/brasil-e-o-2-paiscom-mais-usuarios-que-entram-diariamente-no-facebook.html>. Acesso em: 04/04/2016.

${ }^{30}$ INNOVARE PESQUISA. 99 Milhões de brasileiros estão no Facebook todos os meses. Disponível em: <http://www.innovarepesquisa.com.br/blog/99-milhoes-de-brasileiros-estao-facebook-todosos-meses/>. Acesso em: 06/04/2016.
}

${ }^{31} \mathrm{G} 1$. MEC divulga resultado preliminar do Censo Escolar 2015. Disponível em: <http://g1.globo.com/educacao/noticia/2015/10/mec-divulga-resultado-preliminar-docenso-escolar-2015.html>. Acesso em: 06/04/2016.

${ }^{32}$ ALTHUSSER, Louis. Op. cit., 1970, p. 65. 
A ideologia não é um processo subjetivo consciente, mas um fenômeno objetivo e subjetivo involuntário produzido pelas condições objetivas da existência social dos indivíduos. Ora, a partir do momento em que a relação do indivíduo com sua classe é a da submissão a condições de vida e de trabalho préfixadas, essa submissão faz com que cada indivíduo não possa se reconhecer como fazedor de sua própria classe ${ }^{33}$

Sem uma consciência crítica de sua condição social e das teias de relações socioeconômicas e políticas que norteiam as veredas percorridas em sua trajetória, o sujeito não pode se reconhecer como atuante em sua própria história. Outros a escrevem. Isso contribui para que ele se afaste cada vez mais do lugar que ocupa na sociedade, vivendo de maneira análoga ao que apregoa o senso comum acerca da "naturalidade" dos acontecimentos cotidianos em seu meio, assimilando-os passivamente e perpetuando a inalteração de sua condição social.

Essa via de análise permite afirmar que o lócus privilegiado que já existira para a propagação de ideologias que testificavam e perpetuavam a alienação da força de trabalho se transformou e migrou para outros territórios abertos e acessíveis, sem um interlocutor ou mediador definido claramente.

A pretensão que se tem com isso não é apenas reproduzir a qualificação dos operários no esquema de produção capitalista vigente, mas, além disso, pretende-se que seja feita também a:

[...] reprodução de sua submissão às normas de ordem vigente, isto é, uma reprodução da submissão dos operários à ideologia dominante por parte dos operários e uma reprodução da capacidade de perfeito domínio da ideologia dominante por parte dos agentes de exploração e repressão, de modo a que eles assegurem também "pela palavra" o predomínio da classe dominante ${ }^{34}$

Essa concepção ajuda a corroborar a ideia de que, quanto mais padronizado for o modo como os sujeitos veem o mundo, mais fácil será a manipulação deles e sua adesão às ideologias da classe à qual estão econômica e ideologicamente submetidos.

\footnotetext{
${ }^{33} \mathrm{CHAUI}$, Marilena. Op. cit., p. 72.

${ }^{34}$ ALTHUSSER, Louis. Op. cit., 1985, p. 58.
}

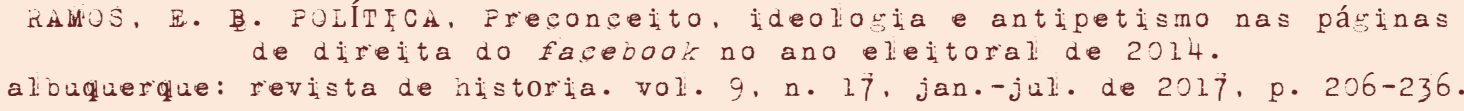


Tal percepção, apesar de poder ser facilmente constatada na sociedade atual, incita um sentimento de preocupação,já queem uma sociedade claramente dividida em classes sociais se pode deduzir "[... que cada qual devesse ter suas próprias ideias $[. . .]^{735}$. No entanto, "[...] a dominação de uma classe sobre as outras faz com que só sejam consideradas válidas, verdadeiras e racionais as ideias da classe dominante" ${ }^{\text {"36. }}$. E essa realidade engendrada ideologicamente é facilmente absorvida pelas demais classes.

\section{uma visão das ideologias no facebook: a "direita" e 0 antipetismo mostram a sua cara na rede em 2014}

Há al gum tempo, a existência da dualidade Esquerda e Direita vem tomando espaço considerável neste conflito de origem política no Facebook. Embora as nuances neoliberais dadas ao mundo do capital nos anos 1990 tenham alardeado 0 suposto fim destes conceitos antagônicos,$^{37}$ eles não desapareceram como tentou alardeou a Direita, a fim de pulverizar conflitos inerentes à luta de classes, dentre outras coisas.

A noção de polarização na política nasceu sob a égide da Revolução Francesa "com a reunião dos chamados Estados Gerais, em Versalhes, quando os defensores do poder real se sentaram no lado direito da sala ${ }^{\text {"38 }}$. Segundo o mesmo autor, nesta ocasião, os significados dados à Direita era o de uma aristocracia burguesa que pretendia conciliar poder real e liberdades individuais. A Esquerda representava assumidamente o sentido da ruptura do status quo e apregoava uma determinação pela supressão da elite aristocrática em nome da soberania popular.

A tualmente, pode-se definir a Direita como a continuidade de uma ten dência política conservadora, determinada a se manter em situação privilegiada socialmente, desmerecendo o que lhe é diferente, calcada no pessimismo antropológico, na negação de qualquer outro tipo de tendência política considerada utópica, na defesa incondicional da propriedade privada, no nacionalismo, no organicismo, dentre outras bases. ${ }^{39}$

Em contraposição a tal postura, pode-se considerar que a que Esquerda seja uma tendência política calcada no otimismo antropológico, na aceitação de posições

${ }^{35} \mathrm{CHAUÍ}$, Marilena. Op. cit., p. 85.

${ }^{36}$ Idem.

37LASSANCE, Antonio. Carta Maior, $2013 . \quad$ Disponível em: <<http://www.cartamaior.com.br/?/Coluna/-Direita-e-Esquerda-razoes-e-confusoes-1/29380>>. Acesso em: 29/04/2014).

${ }^{38}$ MALTEZ apud CRUZ, Pedro Lopes da.Ideologias Políticas: Direita e Esquerda em Cabo Verde de 1975 a 2010. 2012. Dissertação (Mestrado em Ciência Política) - Universidade Técnica de Lisboa, Lisboa, 2012. 78 p, p. 23.

${ }^{39}$ PINTO apud CRUZ, Pedro Lopes da.Op. cit., p. 24.

KaMOS, E. B. FoLÍTCA, Freconceito, ideologia e antipetismo nas pásinas de direita do facebook no ano eleitaral de 2014.

albuquerque: revista de historia. val. 9, n. 17, jan.-jul. de $2017, p \cdot 206-236$. 
contrárias, de forma democrática, no igualitarismo, no respeito à condição humana e na defesa de seus direitos, no socialismo, a lém de outras bases características dessa linha de pensamento.

Para Bobbio, pode-se definir que:

\begin{abstract}
[..] a "igualdade" é o princípio que caracteriza a esquerda e a "desigualdade" é a categoria identificadora da direita. Isto é, a esquerda sustenta uma linha que luta pela igualdade social, enquanto a direita é conotada como uma corrente ideológica que considera a desigual dade social uma inevitabilidade ${ }^{40}$
\end{abstract}

Isto posto, o conceito de Esquerda foi utilizado para definir os seguidores da corrente ideológica marxista, no final do séc. XIX, e do legado deixado pósRevolução Russa, passando a designar a corrente política que defendia os interesses do proletariado. Em direção oposta, a Direita passou a ser deslocada para a burguesia política que apregoava e defendia a manutenção do Capitalismo e, consequentemente, de seus privilégios ${ }^{41}$.

Segundo Bobbio ${ }^{42}$, a díade Esquerda/Direita jamais perdeu o sentido. 0 autor faz tal afirmação em contraposição aos que defendem que a distinção se tornou obsoleta após a queda do muro de Berlim em 1990, um dos últimos símbolos concretos da resistência do socialismo. 0 autor parte da visão de que o pensamento de Direita tende a naturalizar as desigualdades enquanto o de Esquerda parte da premissa das lutas sociais para amenizálas. Deste modo, "de um lado estão aqueles que consideram que os homens são mais iguais que desiguais, de outro os que consideram que são mais desiguais que iguais'.3

Os pretensos significados dados ao sentido de Esquerda e o antipetismo que se pôde constatar durante a observação de páginas do Facebook que se assumem "de Direita" é o que será abordado nesta parte do artigo.

Pode-se considerar que a luta travada por uma corrente direitista existente nas redes sociais, especialmente nas enfocadas neste texto, pela manutenção da sociedade de classes e de seus ideais, provém de uma falsa ideia que se proliferava pelos mesmos meios. H avia uma crença generalizada nos grupos que se assumem ser "de Direita" no Facebook de que o Brasil estaria vivendo uma espécie de socialismo e, segundo alguns mais exaltados, até um suposto "comunismo" ditatorial,

${ }^{40}$ BOBBIO apud CRUZ, Pedro Lopes da. Op. cit., p. 27.

${ }^{41}$ MADEIRA, Rafael Machado. Partidos, Programas e o Debate sobre Direita e Esquerda no Brasil. Revista de Sociologia e Política, v. 21, n. 45, p. 149-165, mar./2013, p. 149-165. Disponível em: <http://www.scielo.br/pdf/rsocp/v21n45/a11v21n45.pdf>. Acesso em 30/04/2013.

${ }^{42}$ BOBBIO, Norberto. Direita e Esquerda. São Paulo: UNESP, 2001.

${ }^{43}$ |bidem, p. 121.

KaHos, E. B. FoLÍtica, Freconceito, ideoloğia e antipetismo nas pásinas de direita do facebook no ano eleitaral de 2014.

albuquerque: revista de historia. val. 9, n. 17, jan.-jul. de $2017, \mathrm{p} \cdot 206-236$. 
pelo fato de o PT (Partido dos Trabalhadores) estar cumprindo o terceiro mandato consecutivono Poder Executivo em 2014.

A ntes de julgamentos baseados em juízo de valor é preciso enfatizar que:

O PT surgiu em 1980, apontado pela literatura como uma novidade - ou uma anomalia, um novo sujeito político diferente das outras legendas - na medida em que foi o primeiro partido de massa de origem extraparlamentar, nascido dos movimentos sindicalistas urbanos, com orientação ideológica de esquerda, complexidade institucional, burocrática e atividades constantes nos diretórios regionais.44

Deste modo, o surgimento do Partido angariou para si uma massa de simpatizantes queiam de intelectuais esquerdistas a operários que se identificavam com as demandas sociais defendidas por sua bandeira. É necessário ressaltar também que o PT surgiu em um período no qual as lutas pela democracia, após anos de ditadura militar, já haviam começado a adentrar as agendas populares e a representar al guns anseios das minorias sociais.

Neste sentido, a criação do Partido foi permeada "[..] por uma estrutura de capilaridade que se baseava em múltiplos setores da sociedade, nem sempre facilmente convergentes, como os grupos sindicalistas urbanos, movimentos eclesiais de base, organizações marxistas, estudantes e intelectuais ${ }^{" 45}$, embora tenha agregado boa parte deles.

Nos anos 1990, as justificativas para o petismo, ou o contingente de admiradores do PT, poderiam ser caracterizadas pelo:

[.]estabelecimento de uma estrutura organizacional rígida e hierárquica, com participação cotidiana dos membros, ligação a movimentos sociais de base, conteúdo programático e ideológico socialistas, atuação legislativa de oposição, valores éticos, além de leal dade e coesão partidária. ${ }^{46}$

\footnotetext{
${ }^{44}$ JÚNIOR, Marcelo Alves dos Santos. 2016. A Rede Antipetista na Eleição de 2014. Dissertação (Mestrado em Comunicação), $\quad$ p. $62 . \quad$ Disponível em: <http://www.opiniaopublica.ufmg.br/site/files/biblioteca/Vai-pra-Cuba-A-Rede-Antipetistana-eleic.pdf>. Acesso em: 10/04/2016.

${ }^{45}$ Idem.

${ }^{46}$ Idem.
}

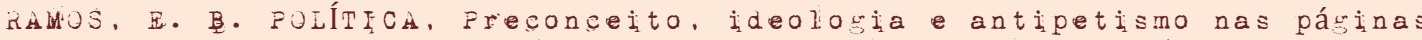
de direita do facebook no ano eleitoral de 2014.

albuquerque: revista de historia. val. 9, n. 17, jan.-jul. de $2017, p \cdot 206-236$. 
Segundo as pesquisas de Júnior ${ }^{47}$, os petistas estavam divididos entre sujeitos com curso superior completo e por grupos assalariados, sendo que em São Paulo também "se concentravam consideráveis índices com baixos níveis de escolaridade. ligados ao sindicalismo e ao trabalho fabri $1^{48}$. Desde meados dos anos 2000 até as eleições de 2014, o PT tomou rumos diferenciados, tentando amenizar os contrastes da luta de classes pela relação dialógica entre elas, o que não agradou parte de seus simpatizantes e nem convenceu antigos antipetistas.

0 antipetismo não é recente, mas surgiu praticamente junto com o PT nos anos 1980. Ele pode ser explicado pelo fato de que, desde a época de seu nascimento, o PT "é o partido mais conhecido, mais organizado, mais falado e, ainda hoje, mais temido por sua capacidade de mobilização popular, ainda que menor em relação a outros tempos.'.9

A tualmente os petistas que ainda acreditam, gostam e defendem o Partido continuam fiéis, mas o PT também perdeu filiados e o antipetismo aumentou. Isso pode ser explicado pelo fato de que:

Sua formação toma vias paralelas que nem sempre reconhecem o desenvolvimento do PT, obedecendo a critérios difusos de acordo com a finalidade e dinâmicas do grupo que se apropria deste discurso.A adequação às forças centrípetas do Estado brasileiro fez com que partido e governo dialogassem com interesses de classes diferentes daqueles da sua base histórica. Mesmo assim, o antagonismo quanto às posições ideológicas e a construção social do PT parece ter tido um efeito de resiliência paradoxal. Talvez referente ao passado esquerdista que ainda alimenta 0 posicionamento político de muitos de seus militantes: ${ }^{50}$

A pesar das controvérsias, isto fez com que o Partido, mesmo perdendo parte de sua personalidade política mais à esquerda, fosse visto em suas gestões consecutivas no Governo Federal brasileiro como uma força das representações dos ideais esquerdistas, segundo as visões do que seja ser "de Esquerda" desenvolvidas por setores tradicionais da sociedade.

Para estes,

\footnotetext{
${ }^{47}$ Idem.

${ }^{48}$ MENEGUELLOapudJÚNIOR, Marcelo Alves dos Santos. Op. cit., p. 65.

${ }^{49}$ PICHONELLI, Matheus. As diversas faces do Antipetismo. GGN, o jornal de todos os Brasis. 2014. Disponível em: <<http://jornalggn.com.br/noticia/as-diversas-faces-do-antipetismo-por-matheuspichonelli>>. Acesso em: 04/04/2016.
}

${ }^{50}$ JÚNIOR, Marcelo Alves dos Santos. Op. cit., p. 81 
[.] o ódio ao PT existiria mesmo que o PT tivesse sido um grande sucesso e o Brasil fosse hoje, depois de 12 anos de pseudossocialismo no poder, uma Suécia tropical. 0 antipetismo é consequência, o ódio ao PT é inato. $O$ antipetismo começou com 0 PT, o ódio ao PT nasceu antes do PT. Está no DNA da classe dominante brasileira, que historicamente derruba, pelas armas se for preciso, toda ameaça ao seu domínio, seja qual for sua sigla.51

Neste sentido, o viés do antipetismo deu vida ao nascimento de disputas acirradas entre os queadmiram o Partido e os queo odeiam. Estefator não configura apenas uma guerra ideológica de Esquerda X Direita, mas algo que tomou proporções muito maiores eque remete aos estádios de futebol quando há o embate verbal e físico entre as grandes torcidas.

Tal fenômeno já pôde ser observado antes, em menor escala, quando Luís Inácio Lula da Silva (Lula, como ficou conhecido publicamente), fundador do PT, concorreu a primeira eleição presidencial no final dos anos 1980.A insegurança com apossível vitória de Lula era latente.'H avia o medo em 1989 de que Lula implantasse o comunismo soviético da foice e martelo. Casas e fazendas seriam invadidas por companheiros. Todo mundo ficaria pobre com a distribuição forçada da riqueza. A té quem nada tinha, nada queria perder ${ }^{152}$

As torcidas por um lado e pelo outro eram clarificadas nas mídias disponíveis na época, sobretudo na televisão.

Um exemplo simbólico para nos ajudar a aclarar essa névoa é o famoso debate entre Collor e Lula na Rede Globo, em 1989. Em recente entrevista, Boni, então diretor da rede, afirmou que os embates entre os candidatos estavam, na sua visão, "muito desiguais", pois Lula era "b povo" e Collor "a autoridade". Para "equilibrar" a disputa, evitando uma desastrosa vitória do "povo", a própria Rede Globo elaborou um cenário forjado, incluindo falsas denúncias contra o candidato do PT53

\footnotetext{
${ }^{51}$ VERÍSSIMO, Luís Fernando. Pragmatismo Político. A diferença entre o antipetismo e o ódio ao PT. 2015. Disponível em: <http://www.pragmatismopolitico.com.br/2015/06/verissimo-a-diferenca-entre-oantipetismo-e-o-odio-ao-pt.html>. Acesso em: 08/04/2016.
}

\footnotetext{
${ }^{52}$ SAMPAIO, Mauro. Do medo ao ódio ao PT. Política Real: a agência da política regional. Disponível em: <<http://www.politicareal.com.br/blogs/brasilia-por-mauro-sampaio/569302/do-medo-ao-odio-aopt>>. Acesso em: 08/04/2016.

${ }^{53}$ BRAGA, Henrique. O segundo turno e os inimigos do PT. Huffpost Brasil. 2014. Disponível em: <http://www.brasilpost.com.br/henrique-braga/o-segundo-turno-e-os-inimigos-do-pt_b_5939134.html>. Acesso em: 13/04/2016.
}

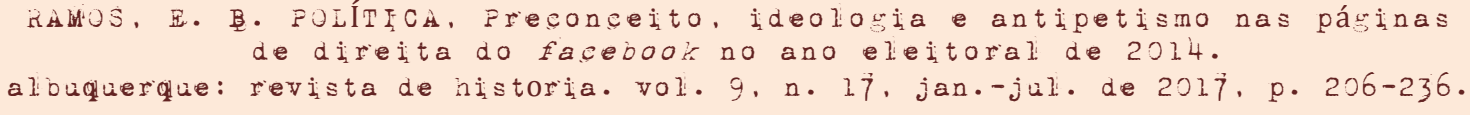


Em 2014, ano das últimas eleições presidenciais, a guerra entre as "torcidas" contra e a favor da reeleç̧ão de Dilma Rousseff, do PT, para a Presidência da República voltou à tona com muito mais força via redes sociais.

O uso de imagens nas postagens em algumas páginas "de Direita" pesquisadas foi bastante expressivo. A análise dessas imagens, que também trazem textos, traduz ideologias que se aproximam de uma corrente de pensamento de Direita, repleta de contradições.

A ntes de tecer análises sobre as imagens retiradas dessas páginas do Facebook, é preciso contextualizálas historicamente no recorte de tempo em que foram criadas e reproduzidas. Peter Burke atenta para o fato de que é preciso saber, além das circunstâncias em que a imagem foi produzida, qual a intenção de seu autor no contexto determinado. ${ }^{54}$

Para tornar a análise mais pontual, exalta-se que o recorte temporal das imagens elencadas neste artigo foi feito entre os meses de abril e maio de 2014 e, apesar das eleições presidenciais estarem marcadas para outubro do mesmo ano, 0 foco dessas páginas já estava em denegrir a imagem do PT e de alguns programas sociais implementados em suas gestões.

A pesar das postagens a serem tratadas nesse texto serem baseadas em leituras superficiais e preconceituosas de mundo, é preciso enfocar que elas têm poder para transformar mentalidades e delinear ações antiéticas, mesmo sendo repletas de juízos de valor arraigados no senso comum.

0 antipetismo pode ser observado no post de um grupo do Facebook intitulado União Nacional Anti-PT, em 2014, ano da última eleição presidencial, traduzido na imagem seguinte:

${ }^{54}$ BURKE, Peter. Testemunha Ocular: história e imagem. 2. ed. Bauru: EDUSC, 2004.

Ramos, E. B. FOLÍTCA, Freconceito, ideologia e antipetismo nas pásinas de direita do facebook no ano eleitaral de 2014.

albuquerque: revista de historia. val. 9, n. 17, jan.-jul. de 2017, p. 206-236. 
Figura 1 - Postagem da página “União Nacional Anti-PT”.

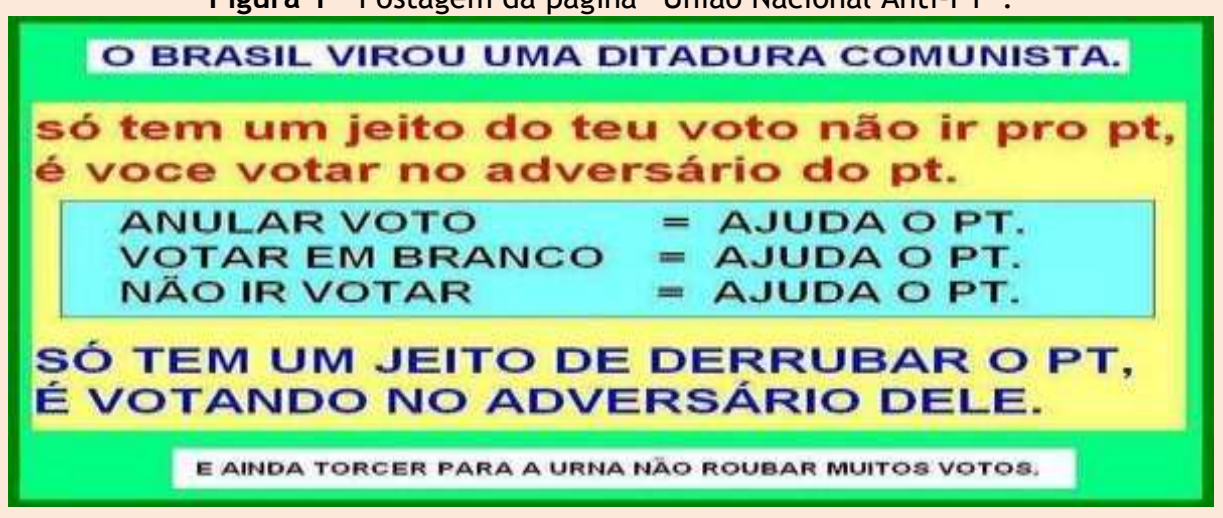

Fonte: Facebook.com ${ }^{55}$

Essa página contava com 508 membros no recorte temporal da pesquisa. Quanto ao seu perfil, além de ser claramente contrário ao Partido dos Trabalhadores, este grupo insinua que há fraude nas eleições brasileiras, mesmo em tempos de urnas eletrônicas e vigilância acirrada. H á postagens na referida página que afirmam que o Partido da situação venceu as eleições às custas de manipulação fraudulenta no processo eleitoral. Por fim, à época das eleições de 2014, a página incitava seus seguidores a votarem em um dos candidatos da oposição, o senador A écio N eves do PSDB (Partido da Social Democracia Brasileira).

O Facebook tem o recurso "curtir", um botão através do oual os usuários podem clicar como uma demonstração de empatia pelo conteúdo da postagem. Outro desses dispositivos virtuais é a opção "compartilhar", na qual o internauta replica em sua linha do tempo e, consequentemente, para seu grupo de amigos ou para todo o público - a depender das configurações de privacidade - o conteúdo postado originalmente pela página. 0 post citado, por exemplo, teve poucas "curtidas" mas, em contrapartida teve 910 compartilhamentos até a data em que fora visto $\bigcirc$ ato de "curtir" e o de "compartilhar", mais do que índice de "audiência" da página ou de "visualização", é um mecanismo de engajamento, pois necessita da predisposição do usuário numa ação.

U ma outra página, intitulada "TV Revolta", também caminhava na mesma direção no ano eleitoral de 2014. Em uma das postagens destegrupo se pode observar o tom irônico quando trata Lula e a presidente Dilma Rousseff como uma dupla sertaneja singular.

${ }^{55}$ Disponível

em:

<https://www.facebook.com/photo.php?fbid=791771127501007\&set=a.413969301947860. $103154.100000043800848 \&$ type $=1 \&$ theater $>$. Acesso em 22/04/2014.

Kamos, E. B. FOLÍTCA, Freconceito, ideolosia e antipetismo nas pásinas de direita do facebook no ano eleitaral de 2014.

albuquerque: revista de historia. vol. 9, n. 17, jan.-jul. de 2017, p. 206-236. 
Figura 2: Postagem da página "TV Revolta".

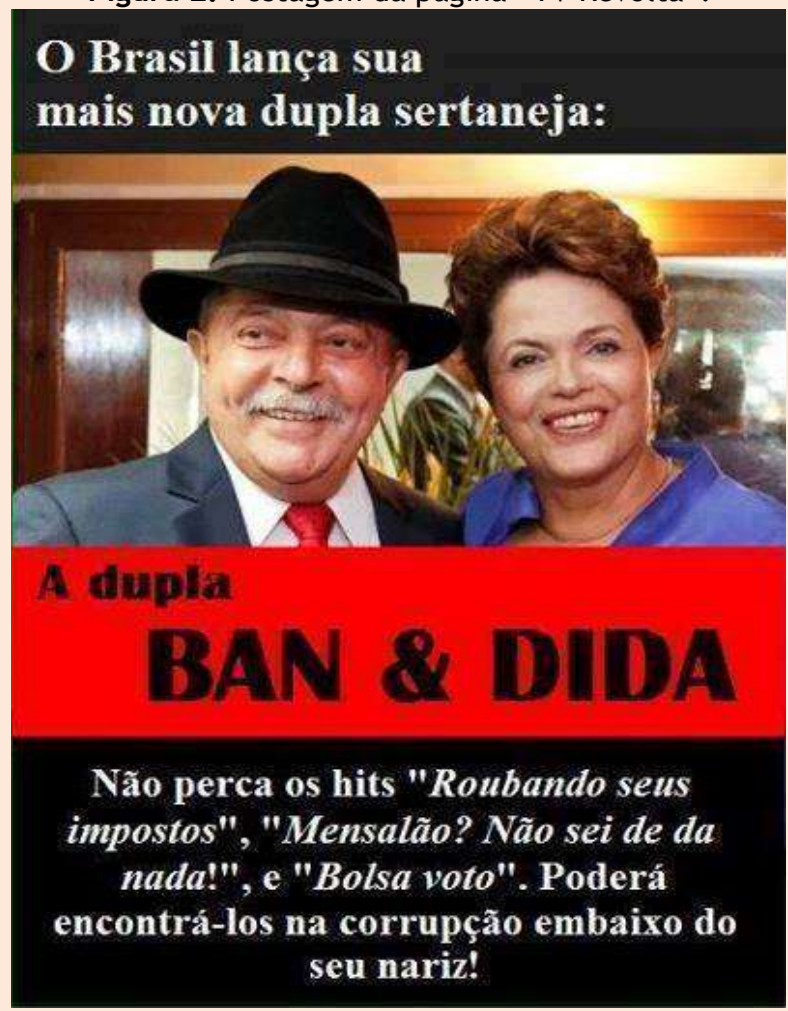

Fonte: Facebook.com ${ }^{56}$

Essa imagem teve quase sete mil curtidas e ultrapassou os sete mil compartilhamentos até a data pesquisada. Mais uma vez, pode-se observar o uso intencional de determinadas cores para transmitir mensagens subliminares. Os termos "Ban \& Dida" aparecem grafados sob a tonalidade vermelha de fundo - cor usada no emblemado Partido dos Trabalhadores - enquanto o restante da mensagem está escrito sob fundo preto, o que pode simbolizar o sentimento de pesar pelo fato de o PT estar no poder político.A s duas cores ajudam a conferir uma aura mais pesada ao que se tentava transmitir com a figura.

As referências às denúncias do envolvimento do PT em esquemas de corrupção ficam claras na imagem e o apelo intencional ou não pela mobilização de quem a vê também, quando afirma em seu texto que tal corrupção está "embaixo do seu nariz!", o que parece uma tentativa de incitação à revolta do leitor da mensagem.

\footnotetext{
${ }^{56}$ Disponível 
A TV Revolta e a U nião N acional A nti-PT não se definem como páginas de Direita, mas denotam em suas postagens a clara oposição ao governo petista. Os argumentos de ambas para o antipetismo pareciam estar sempreembasados no que as mídias massivas noticiavam cotidianamente a respeito da política, principalmentenos jornais televisivos.

Pode-se afirmar que "o termo cultura política, durante muito tempo reservado às elites capazes de formular claramente a ideologia, passou a ser aplicado à massa daqueles que têm opiniões políticas, qual quer que seja seu nível cultural,e ainda que não estejam em condição de sustentar uma discussão teórica ${ }^{57}$ o que cabe bem às discussões políticas nas redes sociais.

As páginas facebookianas tratadas adiante se declaram "de Direita". No grupo denominado "Direita Realista" foi publicada a figura seguinte, explicando, de antemão, aos usuários e possíveis participantes o que seus idealizadores defendem como agentes da Direita:

Figura 3: Postagem de "Direita Realista”.

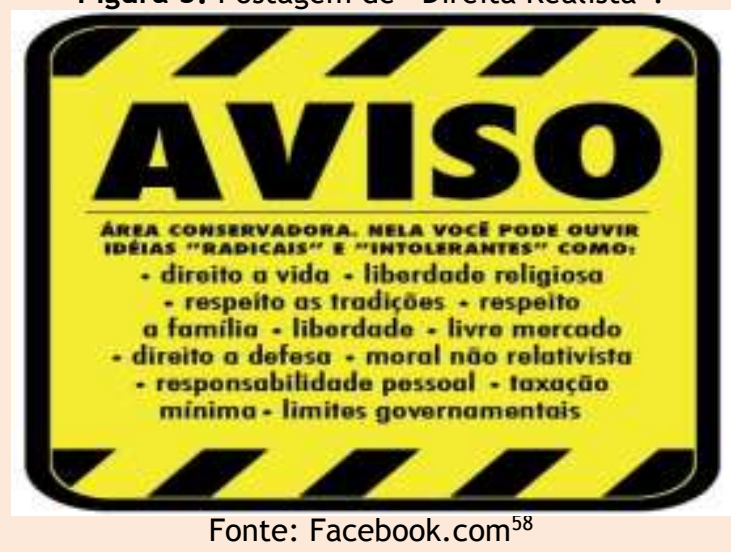

Ironicamente, a imagem simula um aviso que remete a locais perigosos ou restritos, o que denota que o acesso a esteterritório não épara todos. 0 texto inserido na figura se refere a "ideias 'radicais' e intolerantes", fazendo uma alusão ao que consideram que a Esquerda pense sobre a Direita, esclarecendo a seguir que defendem, por exemplo, o direito à vida, o que é direito de todos. A firma defender, também, as liberdades individuais, o livre mercado, a liberdade religiosa, conceitos retirados das revoluções burguesas do séc. XVIII. No entanto, afirma também defender uma "moral não relativista" e o "respeito às tradições"

Em vista disso, pode-se afirmar que:

57 BERSTEIN, Serge. Os Partidos. In: Por uma História Política. 2. ed. Rio de Janeiro: Editora FGV, 2003, p. 88.

${ }^{58}$ Disponível em: https://www.facebook.com/DireitaRealista/photos/a.551196508225468.134269. 551192814892504/551200688225050/?type=1\&theater. Acesso em: 22/04/2014.

KayOS, E. B. FOLÍTCA, Freconceito, ideološia e antipetismo nas pásinas de direita do facebaok no ano eleitaral de 2014.

albuquerque: revista de historia. val. 9, n. 17, jan.-jul. de 2017, p. 206-236. 
[.] cada grupo dispõe da ideologiaque convém ao papel queeledeve preencher na sociedade de classe:papel de explorado (a consciência "profissional", "moral", "civica", "nacional", e apolítica totalmente "desenvolvida"). Papel de agente da exploração (saber comandar, fazer-seobedecer "sem discussão", ou saber manipular a demagogia da retórica dos dirigentes políticos), ou de profissionais da ideologia (saber tratar as consciências com o respeito, ou seja, o desprezo, a chantagem, a demagogia que convêm, com as ênfases na moral, na virtude, na "transcendência", na nação [..].59

O que se pode apreender disso, ao fazer uma análise dosposts da página, é que grupos como estes se configuram mais como "profissionais da ideologia" e que seus membros parecem trabalhar gratuitamente em nome da situação que já parecia perpetuada na História do Brasil, usando como embasamento discursos moralistas e moralizantes a respeito da corrupção e da criminalidade que sempre foram latentes no contexto político brasileiro.

0 preconceito e a intolerância são características muito fortes nestas páginas. As análises socioeconômicas feitas pelos seus membros ultrapassam os limites do senso comum.

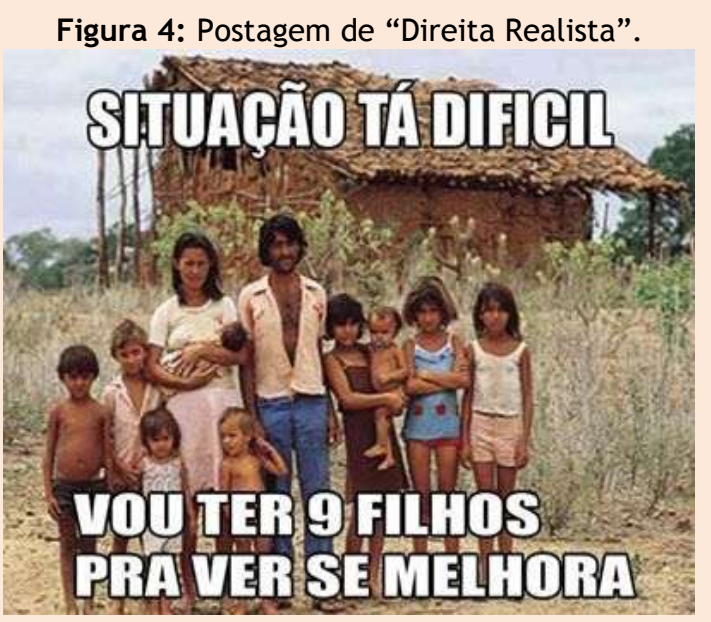

Fonte: Facebook.com ${ }^{60}$

$\mathrm{Na}$ imagem, pode-se ver uma família aparentemente numerosa e não abastada. A moradia singela e os personagens da imagem remetem ao cotidiano de

\footnotetext{
${ }^{59}$ ALTHUSSER, Louis. Op. cit., 1985, p. 80.
} 
al gumas famílias de pequenas cidades nordestinas. $O$ texto inserido na imagem faz uma alusão ao Benefício intitulado Bolsa-Família que "é um programa federal de transferência direta de renda a famílias pobres (com renda mensal per capita de R\$ 70,00 a R $\$ 140,00$ ) e extremamente pobres (com renda mensal per capita de até $R \$$ $70,00^{\prime \prime 61}$. Tal auxílioé duramente criticado pela maioria dos opositores políticos do Partido dos Trabalhadorese por uma parcela da população que acredita que ela é usada pelo Governo como uma forma de se manter no poder pelo voto popular.

0 post teve setenta enove compartilhamentos e 125 "curtidas". A quantidade de compartilhamentos não foi tão expressiva, mas a disseminação de postagens como essasno Facebooké recorrente. O Bolsa-Família não se caracteriza por uma forma passiva de se receber um ben efício, mas há condições para que cada família tenha direito a ele. "[..] Acompanhar, em parceria com os sistemas de ensino, a condicionalidade em educação de estudantes beneficiários do Programa Bolsa Família", é é um dos requisitos. Além disso. "na área da Saúde, as condicionalidades são compromissos assumidos pelas famílias beneficiárias que tenham em sua composição crianças menores de 7 anos elou gestantes"63, que só recebem 0 benefício se cuidarem da vacinação e da saúde delas e do grupo familiar como um todo.

A desinformação sobre esse tema parece ser cuidadosamente engendrada na mídia. A cerca desta discussão:

Como não mencionar os efeitos negativos da mídia sobrea cultura e 0 debate público? Supostamente destinada a informar-nos, ela mais nos desinforma em função de interesses sensacionalistas [.] ou políticos [.]. Em vez de elevar o nível do debate público, a mídia transforma política em espetáculo. Em vez de promover uma cultura de qualidade, ela nos proporciona variedades insípidas [.] Tem como função formar o discernimento eo espírito crítico, mas com muita frequência a lógica da mercantilização faz que a reflexão seja abandonada em favor da emoção, e a teoria, em favor do uso prático: ${ }^{64}$

Neste sentido, é possível afirmar que, em diversas situações cotidianas, as mídias massivas, como os jornais televisivos, por exemplo, tomam partido de causas que interessam à sua classe social, manipulam as notícias, dando muita visibilidade

\footnotetext{
${ }^{61}$ CAMPELLO, Tereza; NERI, Marcelo Côrtes (org.). Programa Bolsa Família: uma década de inclusão e cidadania. Brasília: IPEA, 2013, p. 95.

${ }^{62}$ Ibidem, p. 113.

${ }^{63}$ Ibidem, p. 95.

${ }^{64}$ LIPOVETSKY, Gilles. Op. cit., p. 44.
}

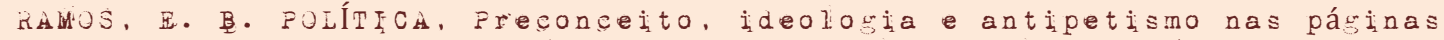
de direita do facebook no ano eleitaral de 2014.

albuquerque: revista de historia. val. 9, n. 17, jan.-jul. de $2017, p \cdot 206-236$. 
a algumas e pulverizando outras, baseadas no que pode ser comprovado por dados de pesquisas e relatos reais.

A ideologia traduzida por essas mídias e presente nestes posts pode:

\begin{abstract}
[.] fazer com que no lugar dos dominantes apareçam ideias "verdadeiras". Seu papel é o de fazer com que os homens creiam que tais ideias representam efetivamente a realidade. E, enfim, também é seu papel fazer com que os homens creiam que essas ideias são autônomas (não dependem de ninguém) e representam realidades autônomas (não foram feitas por ninguém). ${ }^{65}$
\end{abstract}

Crer que as ideias que aparecem no Facebook são autônomas ou que não representam ninguém parece ter se naturalizado.Qualquer pessoa pode criar um post ou um comentário que dê início a uma discussão. Porém, o viés ideológico destas postagens não é relevado quando elas são compartilhadas ou comentadas.

Figura 5: Postagem de “Canal da Direita”.

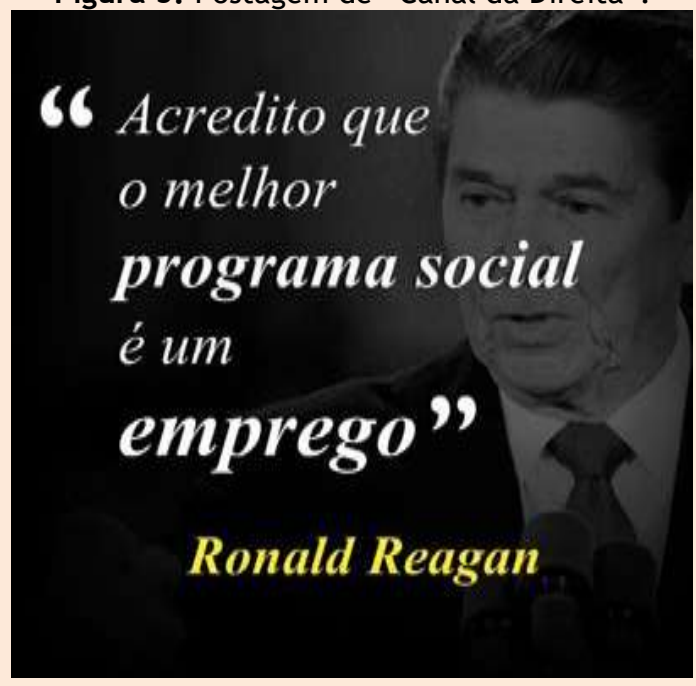

Fonte: Facebook.com ${ }^{66}$

Como uma referência claramente oposta aos programas sociais implementados pelo governo atual, especificamente o Bolsa-Família, este post teve 1200 curtidas até a data referida, além de 872 compartilhamentos.

${ }^{65} \mathrm{CHAUI}$, Marilena. Op. cit., p. 80. 
A oposição ao Programa Bolsa Família fica clara nos comentários (mais um dos recursos disponíveis no Facebook) dos curtidores da página. Um deles afirma que "[..] como existe o bolsa família, prefere-se ficar vagabundando e fazendo filho pra aumentar a renda" ${ }^{\circ 7}$ Outro deles afirma, referindo-se a suposta frase de Reagan e ao governo petista:

Elena época acreditava.Eu não acredito, tenho émuitaCERTEZA ! Como diz o proverbio chinês: 0 importante não é dar os peixe, mas sim ensinar a pescar!!'Só que isso eles (o PT e seus agregados) não querem.. Por que dá e garante a liberdade do cidadão (o povo), e com isto não se conquista votos, e assim se perpetuar no governo.." 68

Esses tipos de comentários denota o desconhecimento de parcela da população sobre o Programa Bolsa Família e, além disso, sobre a H istória do país. Ideologicamente, estes sujeitos parecem acreditar que o emprego e a sua manuten ção dispensa qualquer necessidade de políticas públicas sociais.

N otase neste caso que a ideologia dominante aí aparece como:

[..] um corpo explicativo (representações) e prático (normas, regras, preceitos) de caráter prescritivo, normativo, regulador, cuja função é dar aos membros de uma sociedade dividida em classes uma explicação racional para as diferenças sociais, políticas e culturais, sem jamais atribuir tais diferenças à divisão da sociedade em classes e partir das divisões na esfera da produção. ${ }^{69}$

A s representações que se pode notar nos comentários destas postagens vão ao encontro das asserções de Marilena Chauí, principalmente quando eles se configuram como crenças naturais na ideologia dominante que despreza ou considera inexistente a luta de classes.

Na página "Direita Unida", pode-se encontrar a seguinte postagem:

\footnotetext{
${ }^{67}$ Comentário de um dos curtidores da página “Canal da Direita” a respeito da imagem.

${ }^{68}$ Comentário de outrointernauta a respeito da imagem postada na página “Canal da Direita”.

${ }^{69} \mathrm{CHAUI}$, Marilena. Op. cit., p. 108-9.
}

RHMOS, E. B. FOLÍTCA, Freconceito, ideologia e antipetismo nas pásinas de direita do facebook no ano eleitaral de 2014.

albuquerque: revista de historia. val. 9, n. 17, jan.-jul. de 2017, p. 206-236. 
Figura 6: Postagem de "Direita Unida"

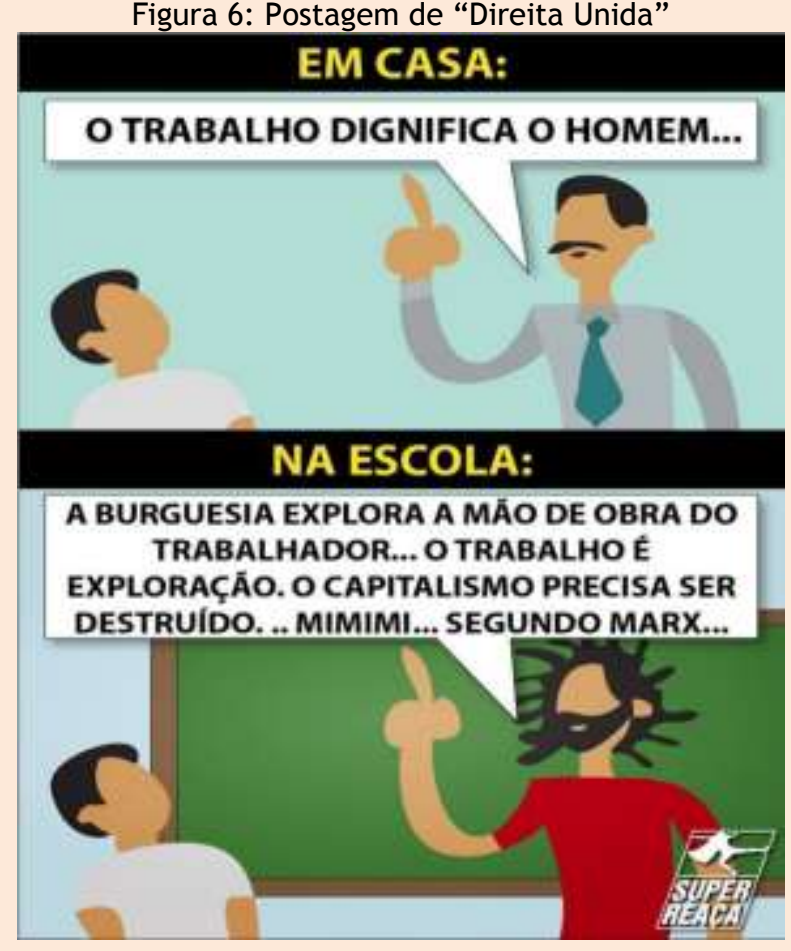

Fonte: Facebook. com $^{70}$

A imagem traz a representação de duas situações: a educação familiar e a escolar. Pelo texto inserido nela, o que se aprende na família se sobrepõe ao ensino institucional quando o assunto tem origem nas correntes históricas e filosóficas de pensamento, dando a impressão de que a aprendizagem elaborada, baseada em visões de mundo diversas, pode estabelecer uma relação conflituosa com 0 pensamento da família. A criança aparece na mesma posição nas duas imagens: a de receptor passivo da mensagem. 0 que muda são os atores adultos. Enquanto o pai do menino usa gravata, símbolo de prestígio social, e tem cabelos e barba curtos, 0 professor, ao contrário, é representado de cabelos e barba grandes, além de usar a cor vermelha que, historicamente, remete à Esquerda.

Essa imagem foi curtida por 66 usuários e compartilhada por 36. Pode-se observar nela que novamente a ideologia dominante do trabal hador acrítico aparece como sendo a "correta", enquanto as vertentes ideológicas das teorias marxistas são deturpadas e ridicularizadas por essas páginas "de Direita". Segundo a figura, o pai 
ensina o que lhe parece o correto ao filho e a escola, nesse caso, retira a validade absoluta desses valores. seguinte figura:

Na página de um grupo denominado "Díreita Política", pode-se encontrar a

Figura 7: Postagem de “Direita Política”.

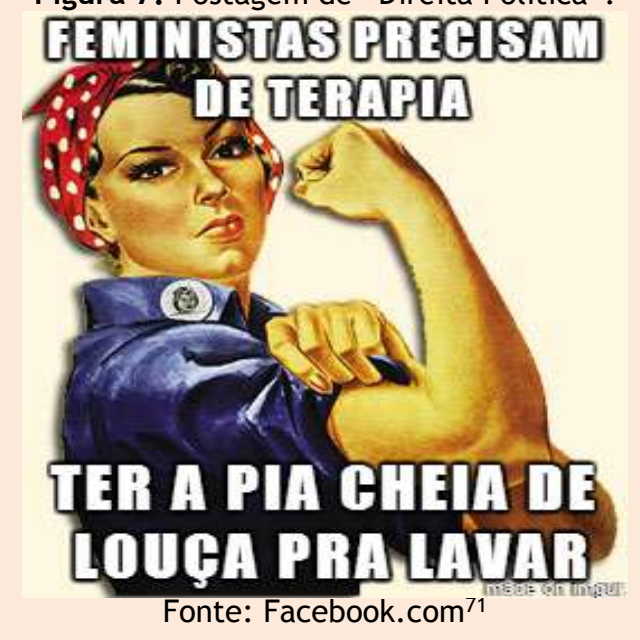

Essa imagem mostra uma mulher em uma pose gestual impositiva para denotar que não está suscetível. Com 189 "curtidas" e 94 compartilhamentos, essa figura e, consequentemente, a ideologia que ela traz, parecem traduzir o que a maioria dos componentes destes grupos pensa sobre os movimentos pelos direitos das minorias. Os comentários abaixo da figura, na rede social, são os mais ofensivos possíveisemrelação à mulher. Pelo conteúdo difamatório, o machismo ea linguagem imprópria utilizada em forma de xingamentos contra as mulheres que defendem suas demandas, não érelevante reproduzir o quefoi comentado a respeito dafigura, mas é preocupante que ideias como essas sejam defendidas como "de Direita" e sejam acatadas por muitos como naturais.

O machismo, que ainda é latente na sociedade brasileira, também é responsável pelo antipetismo que se instalou na Rede. 0 mesmo palavrório impróprio já era usado, no Facebook, contra a presidente Dilma Rousseff (PT) desde que concorreu e venceu as eleições presidenciais em 2010. A incidência de xingamentos, tipicamente machistas, contra ela aumentou durante todo o seu primeiro mandato e se agravou em 2014 quando concorria ao segundo. Qualquer falha governamental era exaltada na Internet mais pelo fato de a presidente ser mulher do que por qualquer outra justificativa. 
Figura 8: Postagem de “Direita Política”.

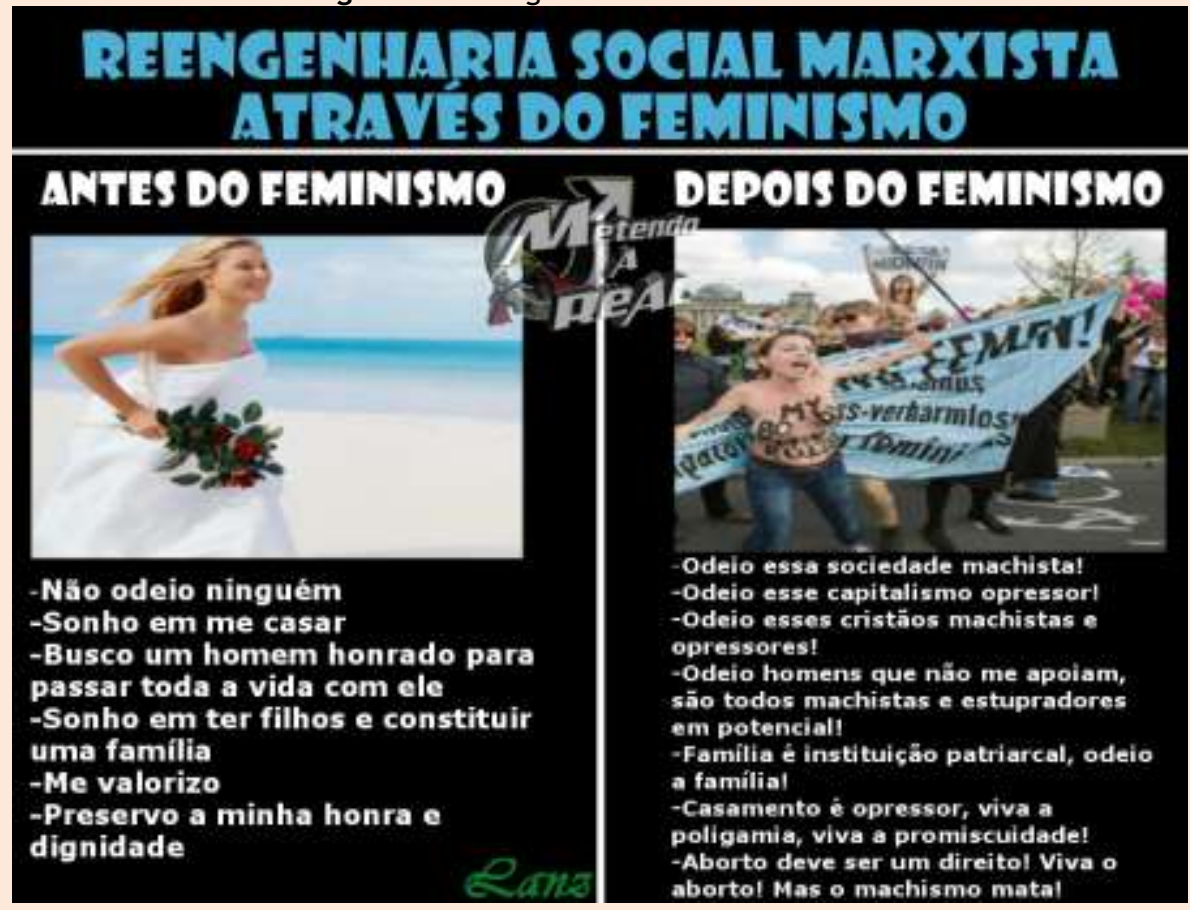

FONTE: Facebook.com ${ }^{72}$

Retirada da mesma página, essa figura denota a ideologia que se propaga em grupos como esses nas redes sociais. A figura contrapõe dois tipos de mulher, a considerada "ideal" pelos setores tradicionais da sociedade e a considerada "sem valor" moral por ser feminista.

Segundo o idealizador da postagem:

O método de reengenharia social marxista, basicamente, transforma pessoas comuns em esquizofrênicas que veem opressão em tudo queexiste. Mas a palavra "bpressão"é substituída por outras palavras, dependendo do movimento de esquerda, que no caso do feminismo pode ser trocada por 'machismo [.]"73

${ }^{72}$ Disponível

em:

<https: / /www.facebook.com/photo.php?fbid=618911861524246\&set=a. 319898058092296 .

73906.307492775999491\&type=1\&theater>. Acesso em: 05/05/2014.

${ }^{73}$ Mensagem do administrador da página” Direita Política” no Facebook em 2014.

nhMos, E. B. FOLÍtica, Freconceito, ideologia e antipetismo nas pásinas de direita do facebaok no ano eleitaral de 2014.

albuquerque: revista de historia. val. 9, n. 17, jan.-jul. de 2017, p. 206-236. 
0 post foi curtido por 80 pessoas e compartilhado por 40 . Embora o número não seja tão significativo, só denota que as lutas das mulheres precisarão estar em evidência por muito tempo ainda enquanto existirem sujeitos que pensam deste modo e que veem as lutas feministas sob a ótica ideológica do preconceito e do desconhecimento.

Michelle Perrot ${ }^{74}$, denuncia que a mulher sempre foi um dos elementos excluídos da História e que essa é contada sempre no masculino. Tal condição passou a ser questionada pelos diversos movimentos feministas nascidos ainda no século X IX, dando voz ativa ao feminino em uma H istória quea deixara emudecida por muito tempo, enquanto toda voz propagada dela era masculina. As lutas travadas pelas mulheres saíram da intimidade de seus lares e tomaram as fábricas, as ruas, as mentalidades de muitas no século XX . No entanto, a luta ainda estásendo travada cotidianamente, visto que os preconceitos ainda aparecem com força.

Posts como estes, além de desqualificarem a luta política das mulheres por direitos básicos, ainda tentam retirar dela seu caráter legítimo ao ridicularizarem as demandas femininas reais, substituindo-as por outras, nem sempre verdadeiras, frutos de ideias errôneas e preconceituosas construídas em torno do movimento.

A página Direita Realista, por sua vez, aliou essa temática à homofobia comum nas chamadas páginas facebookianas "de Direita". Observe a figura:

Figura 9: Postagem de “Direita Realista”.

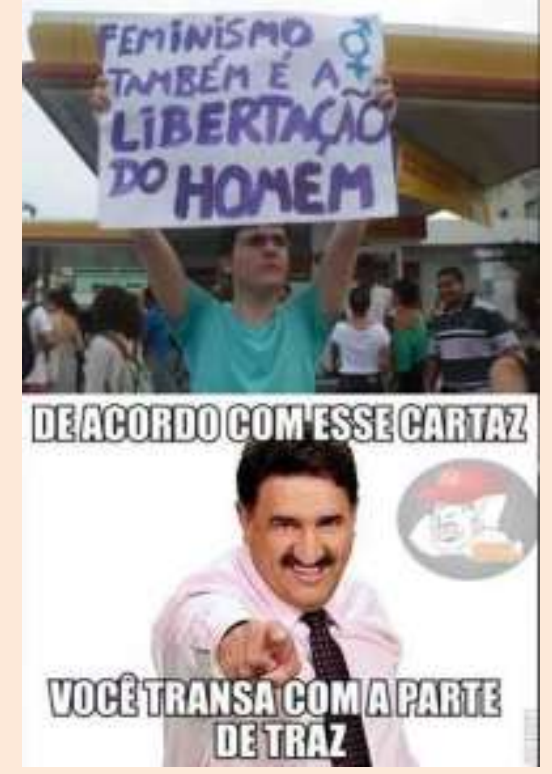

Fonte: Facebook.com ${ }^{75}$

${ }^{74}$ PERROT, Michelle. As mulheres ou os silêncios da história. Bauru, EDUSC, 2005. 
N ela aparece um homem protestan do com um cartaz nas mãos com dizeres alusivos ao feminismo, em contraposição, logo abaixo aparece um apresentador de um programa televisivo popular com dizeres que insinuam a homossexualidade do rapaz que está com o cartaz.

A postagem teve 55 compartilhamentos e 213 "curtidas" até a data analisada. Os comentários a respeito da figura são bastante preconceituosos. Segundo um deles: "Sim $\bigcirc$ feminismo liberta o homem de sua própria testosterona. E a mulher de sua própria vergonha" ${ }^{\text {"76. }}$. Quanto à alusão à homossexualidade contida na postagem, os comentários, além de preconceituosos, ainda remetem, de maneira vexatória, aos modos de se relacionar sexualmente dessa parcela da população e à própria existência dela.

tal crítica.

O post da Direita Política, que pode ser visualizado na figura abaixo, reflete

Figura 10: Postagem de "Direita Política"

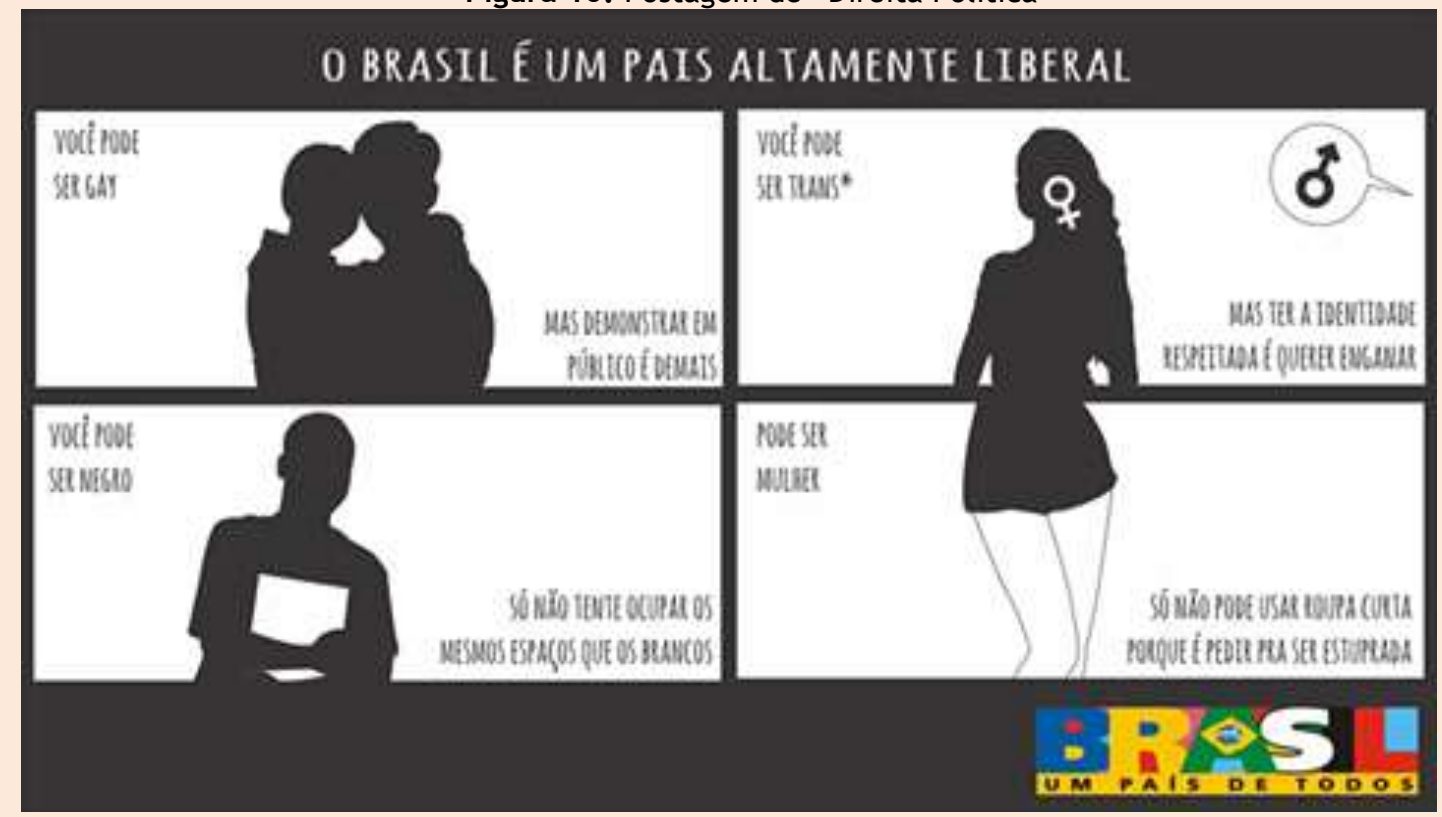

Fonte: Facebook. ${ }^{77}$

A imagem afirma, em tom de crítica, que o Brasil é um país liberal, mas, em seguida, denota o preconceito contra as minorias em seus quadrinhos. 0 texto da imagem afirma que a pessoa pode ser homossexual, mas não demonstrar em

\footnotetext{
${ }^{76}$ Comentário de um curtidor da página "Direita Realista" a respeito da imagem. 
público; pode ser transexual, mas é obrigada a manter na documentação oficial o sexo de nascimento; pode ser negra, mas nunca ocupar o "lugar" dos brancos e pode ser mulher, mas não usar roupas curtas sob o risco de ser estuprada, aludindo que a vítima é responsável por tal violência.

Segundo o pensamento imperante nestas páginas que se autoproclamam "de Direita", o Partido dos Trabalhadores parece ter sido o responsável por trazer demandas sociais das minorias à tona, como se tais problemas não existissem antes.

Quando se refere ao PT, todos estes grupos parecem ter uma posição consensual de ser contra o Partido e sua ideologia. No caso da referência à ocupação dos negros dos "espaços dos brancos", pode-se observar que estes grupos que se assumem "de Díreita" são totalmente contrários às políticas afirmativas, principalmente com relação às cotas para negros em universidades públicas, consideradas por muito tempo, "espaço de branco", dentre outros locais.

\section{considerações finais}

Embora o Facebook seja um profícuo canal de comunicação interpessoal e um espaço privilegiado para práticas democráticas, as pesquisas realizadas para dar vida a este artigo revelaram, em postagens como as citadas, o quanto as discussões incitadas na rede são rasas, mas quão profundamente elas têm poder para transformar mentalidades e delinear ações nem sempre pautadas na lógica, na ética e no senso crítico.

A permanência do Partido dos Trabalhadores no Governo Federal por mandatos consecutivos, conquistados através de eleições diretas, foi o bastante para transformar usuários da Internet, não apenas em críticos impiedosos destas gestões, mas em cidadãos repletos de um sentimento de insatisfação que notadamente tem a sua gênese no antipetismo, o que existe desde a fundação do Partido.

Na mesma via, conflitos gerados no Facebook têm alcançado os patamares do ódio e da intolerância exaltados virtualmente, mas que acabam ultrapassando os limites desses espaços, se traduzindo nas relações cotidianas travadas pelos sujeitos no mundo real. 0 conservadorismo brasileiro sempre existiu, mas era velado e parecia estar "guardado", à espreita de um terreno livre de julgamentos, como parece ser a Internet para alguns.

É preciso refletir com profundidade sobre essas demandas e transformar posicionamentos mais conscientes, humanos e éticos em ações que cheguem às escolas, por exemplo, para que os cidadãos do futuro possam ser formados com base no reconhecimento do próximo como sujeito de direitos subjetivos e sociais. 